Article

\title{
Effect of Ionic Radius in Metal Nitrate on Pore Generation of Cellulose Acetate in Polymer Nanocomposite
}

\author{
Woong Gi Lee ${ }^{1}$, Younghyun Cho ${ }^{2, *}$ and Sang Wook Kang ${ }^{1,3, *}$ \\ 1 Department of Chemistry, Sangmyung University, Seoul 03016, Korea; even004@naver.com \\ 2 Department of Energy Systems Engineering, Soonchunhyang University, Asan 31538, Korea \\ 3 Department of Chemistry and Energy Engineering, Sangmyung University, Seoul 03016, Korea \\ * Correspondence: yhcho@sch.ac.kr (Y.C.); swkang@smu.ac.kr (S.W.K.); Tel./Fax: +82-2-2287-5362 (S.W.K.)
}

Received: 27 March 2020; Accepted: 21 April 2020; Published: 23 April 2020

\begin{abstract}
To prepare a porous cellulose acetate (CA) for application as a battery separator, $\mathrm{Cd}\left(\mathrm{NO}_{3}\right)_{2} \cdot 4 \mathrm{H}_{2} \mathrm{O}$ was utilized with water-pressure as an external physical force. When the CA was complexed with $\mathrm{Cd}\left(\mathrm{NO}_{3}\right)_{2} \cdot 4 \mathrm{H}_{2} \mathrm{O}$ and exposed to external water-pressure, the water-flux through the $\mathrm{CA}$ was observed, indicating the generation of pores in the polymer. Furthermore, as the hydraulic pressure increased, the water-flux increased proportionally, indicating the possibility of control for the porosity and pore size. Surprisingly, the value above $250 \mathrm{LMH}\left(\mathrm{L} / \mathrm{m}^{2} \mathrm{~h}\right)$ observed at the ratio of 1:0.35 (mole ratio of $\mathrm{CA}: \mathrm{Cd}\left(\mathrm{NO}_{3}\right)_{2} \cdot 4 \mathrm{H}_{2} \mathrm{O}$ ) was of higher flux than those of CA/other metal nitrate salts $\left(\mathrm{Ni}\left(\mathrm{NO}_{3}\right)_{2}\right.$ and $\left.\mathrm{Mg}\left(\mathrm{NO}_{3}\right)_{2}\right)$ complexes. The higher value indicated that the larger and abundant pores were generated in the cellulose acetate at the same water-pressure. Thus, it could be thought that the $\mathrm{Cd}\left(\mathrm{NO}_{3}\right)_{2} \cdot 4 \mathrm{H}_{2} \mathrm{O}$ salt played a role as a stronger plasticizer than the other metal nitrate salts such as $\mathrm{Ni}\left(\mathrm{NO}_{3}\right)_{2}$ and $\mathrm{Mg}\left(\mathrm{NO}_{3}\right)_{2}$. These results were attributable to the fact that the atomic radius and ionic radius of the $\mathrm{Cd}$ were largest among the three elements, resulting in the relatively larger $\mathrm{Cd}$ of the $\mathrm{Cd}\left(\mathrm{NO}_{3}\right)_{2}$ that could easily be dissociated into cations and $\mathrm{NO}_{3}{ }^{-}$ions. As a result, the free $\mathrm{NO}_{3}{ }^{-}$ions could be readily hydrated with water molecules, causing the plasticization effect on the chains of cellulose acetate. The coordinative interactions between the $\mathrm{CA}$ and $\mathrm{Cd}\left(\mathrm{NO}_{3}\right)_{2} \cdot 4 \mathrm{H}_{2} \mathrm{O}$ were investigated by IR spectroscopy. The change of ionic species in $\mathrm{Cd}\left(\mathrm{NO}_{3}\right)_{2} \cdot 4 \mathrm{H}_{2} \mathrm{O}$ was analyzed by Raman spectroscopy.
\end{abstract}

Keywords: cellulose acetate; porosity; ionic radius; water-pressure

\section{Introduction}

Nanoporous materials have received much attention for their possibilities of being utilized for gas separation, catalysis, battery separators, medicine, and water treatment [1,2]. Currently, the preparation or synthesis of nanoporous materials has been explosively explored due to showing various and unique characteristics. For instance, the Lei Qian group suggested a special method to generate nanoparticles into porous materials with the evaporation phenomena of solvents [3]. On the other hand, the Dubinsky group showed that polymerization-induced phase separation could generate the hybrid porous material [4]. Recently, unique structures such as porous polymer networks (PPNs), porous organic polymers (POPs), metal-organic frameworks (MOFs) and porous aromatic frameworks (PAFs) have been investigated due to their gas storage characteristics [5-8]. On the other hand, Yiming et al. reported enhanced $\mathrm{CO}_{2}$ uptake through microporous carbon material [9]. Additionally, Atsushi Takase et al. evaluated the $\mathrm{SF}_{6}$ and $\mathrm{N}_{2}$ separation ability of nanoporous carbons using an adsorption mechanism [10]. Moreover, porous materials as separators to improve the efficiency of batteries have 
been receiving attention. Specifically, porous organic materials have made promising candidates for highly efficient battery separators due to their easily tunable morphology by using smart functional materials and chemistry [11-14]. In detail, the lithium ion battery separator was prepared generally with polymers such as polyethylene (PE) or polypropylene (PP) because of their attractive physical and electrochemical stability. However, PP and PE separators have some drawbacks, which would show low wettability, resulting in the low ionic conductivity. Furthermore, low thermal stability played a role as an obstacle for practical applications. To overcome these drawbacks, porous inorganic material, nanoparticle, high thermal-resistance polymer and separator coated thermal material have been used as separator [15-17]. Especially, Meinan et al. developed the thermally stable separator with high performance by using the pure inorganic material [18]. Furthermore, the Lee group reported the thermally stable polyimide nanofiber with $\mathrm{Al}$ oxide particles as separator [19].

To date, porous materials have been formed through a variety of methods such as thermally induced phase separation, evaporation induced phase separation, phase inversion and track-etching [20-22]. For example, Jian Zhao et al. proposed a method to fabricate microporous material using the solvent evaporation-including separation. This method used a ternary solution, such as a liquid silicone rubber precursor of liquid paraffin and hexane, and this solution was cast to form a film. When the hexane and liquid paraffin was removed, micropores from less than 300 to over $1200 \mu \mathrm{m}$ were generated in the silicone rubber film [23]. Hermsdorf et al. suggested the fabrication of porous polyimide film onto a silicon support coated with an oxide layer. Polyimide membranes are used as a starting material for a sample preparation based on the high energy of ion irradiation. As a result, the pore size in the membrane was an average of $73 \mathrm{~nm}$ and the pore shape was conical [24]. However, some problems of these methods are the complications and the high-cost of the process. To solve these drawbacks, our group reported the method to fabricate pores using the ionic liquid and solvated inorganic complex $[25,26]$. The nickel nitrate $\left(\mathrm{Ni}\left(\mathrm{NO}_{3}\right)_{2} \cdot 6 \mathrm{H}_{2} \mathrm{O}\right)$ as inorganic complex was well dissolved in water or acetone and it can be applied to cellulose acetate solution dissolved acetone/water (w/w 8/2). As a result, the pore size and volume of the polymer matrix increased by water pressure and the pores were uniformly distributed [26]. In this study, we suggested the environment-friendly and energy-efficient method to synthesize the pores, which is close to the straight type in a cellulose acetate (CA) polymer matrix [27], using a combination of inorganic complex $\left(\mathrm{Cd}\left(\mathrm{NO}_{3}\right)_{2} \cdot 4 \mathrm{H}_{2} \mathrm{O}\right)$ and isostatic water pressure. Especially, we investigated the effect of the ionic radius in metal nitrate on both the pore generation and pore control of cellulose acetate.

\section{Experimental}

Separator fabrication: polymer (cellulose acetate, Sigma-Aldrich Co. Milwaukee, WI, USA) was dissolved into acetone/water co-solvents. Then, cadmium (II) nitrate hexahydrate $\left(\mathrm{Cd}\left(\mathrm{NO}_{3}\right)_{2} \cdot 4 \mathrm{H}_{2} \mathrm{O}\right.$, Sigma-Aldrich Co. Milwaukee, WI, USA) was incorporated into polymer solution by the mole ratio of the $\mathrm{Cd}$ salts to the monomeric unit of polymer. The prepared mixture was stirred for one hour at room temperature, and then casted for the free-standing film on the plate. Finally, the free-standing films were dried at atmosphere pressure for $30 \mathrm{~min}$. The dried polymer films with $\mathrm{Cd}\left(\mathrm{NO}_{3}\right)_{2} \cdot 4 \mathrm{H}_{2} \mathrm{O}$ were placed into cells such that water molecules could be passed through the composite films. Then, the various water-pressures ranging from 2 to 8 bar were applied to the cells equipped with the polymer composites containing $\mathrm{Cd}\left(\mathrm{NO}_{3}\right)_{2} \cdot 4 \mathrm{H}_{2} \mathrm{O}$. The water flux of the films for varying porosity was measured and expressed as $\mathrm{L} / \mathrm{m}^{2} \mathrm{~h}$.

\section{Results and Discussion}

Scanning electron microscopy (SEM JSM-5600LV, JEOL, Tokyo, Japan) was utilized to observe the pore formation on and in polymers with the $\mathrm{Cd}\left(\mathrm{NO}_{3}\right)_{2} \cdot 4 \mathrm{H}_{2} \mathrm{O}$ additive after being exposed to external water-pressures. Figure $1 \mathrm{a}, \mathrm{b}$ represents the surface morphology of the $\mathrm{CA}$ matrix which was dissolved in acetone/water co-solvents with the $\mathrm{Cd}\left(\mathrm{NO}_{3}\right)_{2} \cdot 4 \mathrm{H}_{2} \mathrm{O}$ additive. The SEM image clearly exhibited that there were abundant pores on the surface when the $\mathrm{CA}$ polymer with $\mathrm{Cd}\left(\mathrm{NO}_{3}\right)_{2} \cdot 4 \mathrm{H}_{2} \mathrm{O}$ 
was exposed to water-molecules, while the pores were not observed in the neat CA polymer even when the water-pressure was applied as in a previous study [28]. Furthermore, the cross-section images of the CA matrix containing the $\mathrm{Cd}\left(\mathrm{NO}_{3}\right)_{2} \cdot 4 \mathrm{H}_{2} \mathrm{O}$ additive shown in Figure $1 \mathrm{c}, \mathrm{d}$ indicate that that pores were well fabricated in the polymers. In contrast, when the neat CA was dissolved in pure acetone, there were no pores on the surface of the polymer. In order to precisely control the pore size and porosity, we introduced the new method to utilize the $\mathrm{Cd}\left(\mathrm{NO}_{3}\right)_{2} \cdot 4 \mathrm{H}_{2} \mathrm{O}$ in acetone/water co-solvent. The resulting SEM image clearly implies that the pore size and porosity of polymer matrix could be controllable by inorganic salts and water-molecules. It was noted that there were two major plausible explanations for these phenomena: (1) the $\mathrm{Cd}\left(\mathrm{NO}_{3}\right)_{2} \cdot 4 \mathrm{H}_{2} \mathrm{O}$ aggregates solvated in the polymer matrix during the solidification while the volatile acetone rapidly evaporated, resulting in the remaining $\mathrm{Cd}\left(\mathrm{NO}_{3}\right)_{2} \cdot 4 \mathrm{H}_{2} \mathrm{O}$ aggregates forming well-defined pores in the CA polymer matrix; or (2) that there were ionic associations between the ions generated from the $\mathrm{Cd}\left(\mathrm{NO}_{3}\right)_{2}$ and the water molecules. These strong interactions delayed the evaporation of the water molecules in the CA polymer matrix, resulting in the formation of pores on the surface.

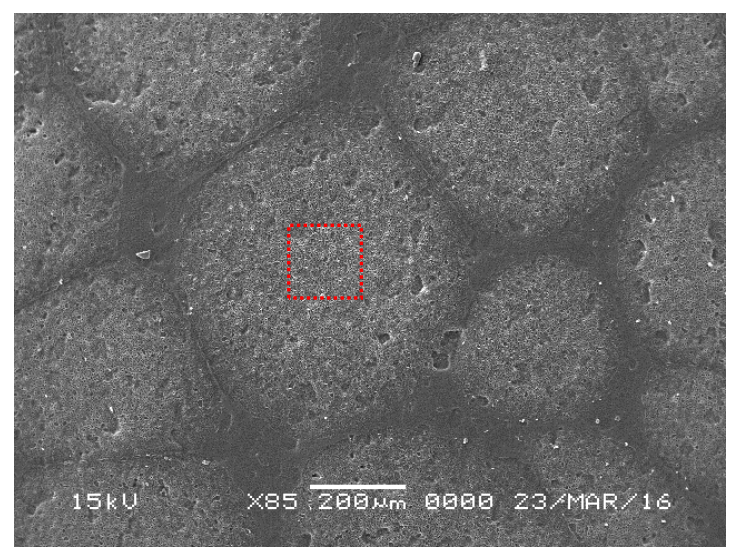

(a)

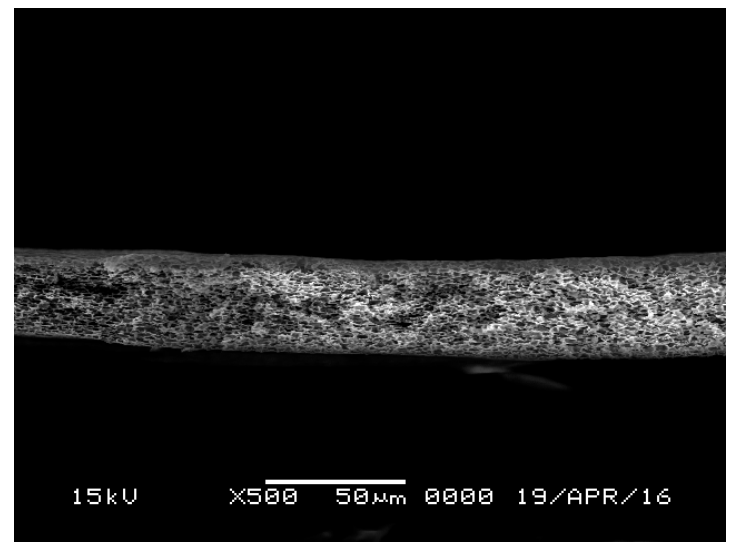

(c)

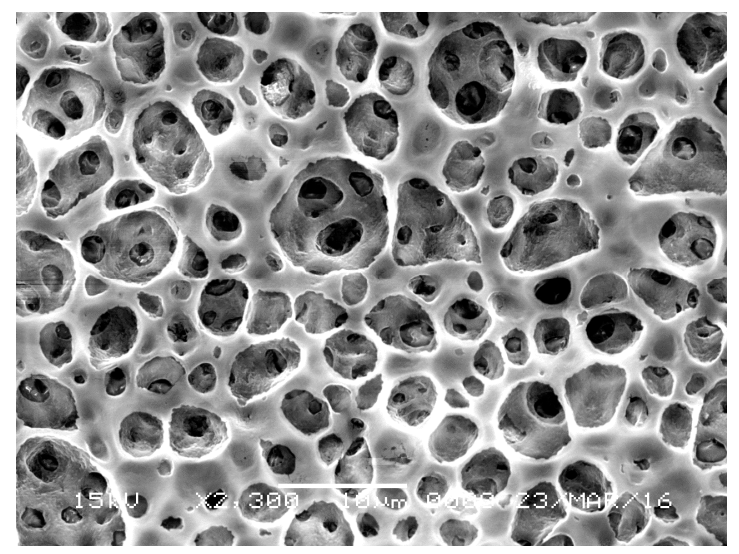

(b)

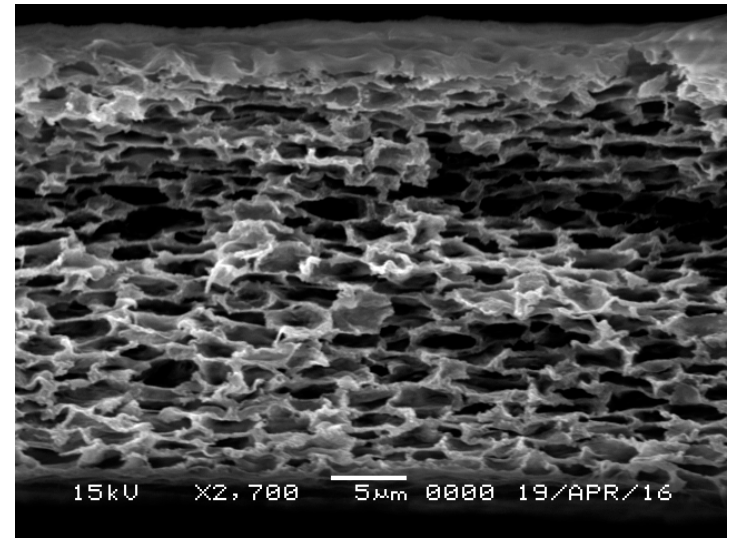

(d)

Figure 1. SEM images: (a) plane view of porous CA polymer exposed to external water-pressures (scale bar $=200 \mu \mathrm{m}),(\mathbf{b})$ the enlarged red-dot square in plane view (scale bar $=10 \mu \mathrm{m}),(\mathbf{c})$ cross-section view (scale bar $=50 \mu \mathrm{m})$ and $(\mathbf{d})$ enlarged view of cross-section (scale bar $=5 \mu \mathrm{m}$ ).

The water flux through the porous CA polymer containing different ratios of $\mathrm{Cd}\left(\mathrm{NO}_{3}\right)_{2} \cdot 4 \mathrm{H}_{2} \mathrm{O}$ is shown in Figure 2. The water flux was not observed up to 2 bar, indicating that pores in $\mathrm{CA}$ polymer were not formed. However, the water flux gradually increased for 1:0.35 and 1:0.40 mol 
ratios $\mathrm{CA} / \mathrm{Cd}\left(\mathrm{NO}_{3}\right)_{2} \cdot 4 \mathrm{H}_{2} \mathrm{O}$ polymer matrix at 3 bar. An explanation for these phenomena is that the water-channel was generated through weakened regions in the CA polymer, resulting in the observation of water-flux. However, the flux of neat CA polymer was not observed up to 7-bar water pressure and the low flux of $2.55 \mathrm{~L} / \mathrm{m}^{2} \mathrm{~h}$ was observed only in the 8-bar water pressure [26]. From these results, it was thought that the CA polymer without $\mathrm{Cd}\left(\mathrm{NO}_{3}\right)_{2} \cdot 4 \mathrm{H}_{2} \mathrm{O}$ was confirmed not to have pores capable of being penetrated for water molecules through the polymer chains. Even though the amounts of $\mathrm{Cd}\left(\mathrm{NO}_{3}\right)_{2} \cdot 4 \mathrm{H}_{2} \mathrm{O}$ beyond the aforesaid ratios could be added, the increase in flux was not observed since the interactions between polymer chains were strengthened by crosslinking phenomena in $\mathrm{CA}$ polymer chains. Therefore, the best performance capable of being easily controllable for pores was the ratio of 1:0.35 for CA/Cd salts. Especially, the value above $250 \mathrm{LMH}\left(\mathrm{L} / \mathrm{m}^{2} \mathrm{~h}\right)$ observed at the ratio of 1:0.35 was higher flux than those of $\mathrm{CA} /$ other metal nitrate salts $\left(\mathrm{Ni}\left(\mathrm{NO}_{3}\right)_{2}\right.$ and $\left.\mathrm{Mg}\left(\mathrm{NO}_{3}\right)_{2}\right)$ complexes. The higher value indicated that the larger and abundant pores were generated in the cellulose acetate with the same physical external forces. Thus, it could be thought that $\mathrm{Cd}\left(\mathrm{NO}_{3}\right)_{2} \cdot 4 \mathrm{H}_{2} \mathrm{O}$ salt played a role as a stronger plasticizing agent than the other metal nitrate salts such as $\mathrm{Ni}\left(\mathrm{NO}_{3}\right)_{2}$ and $\mathrm{Mg}\left(\mathrm{NO}_{3}\right)_{2}$.

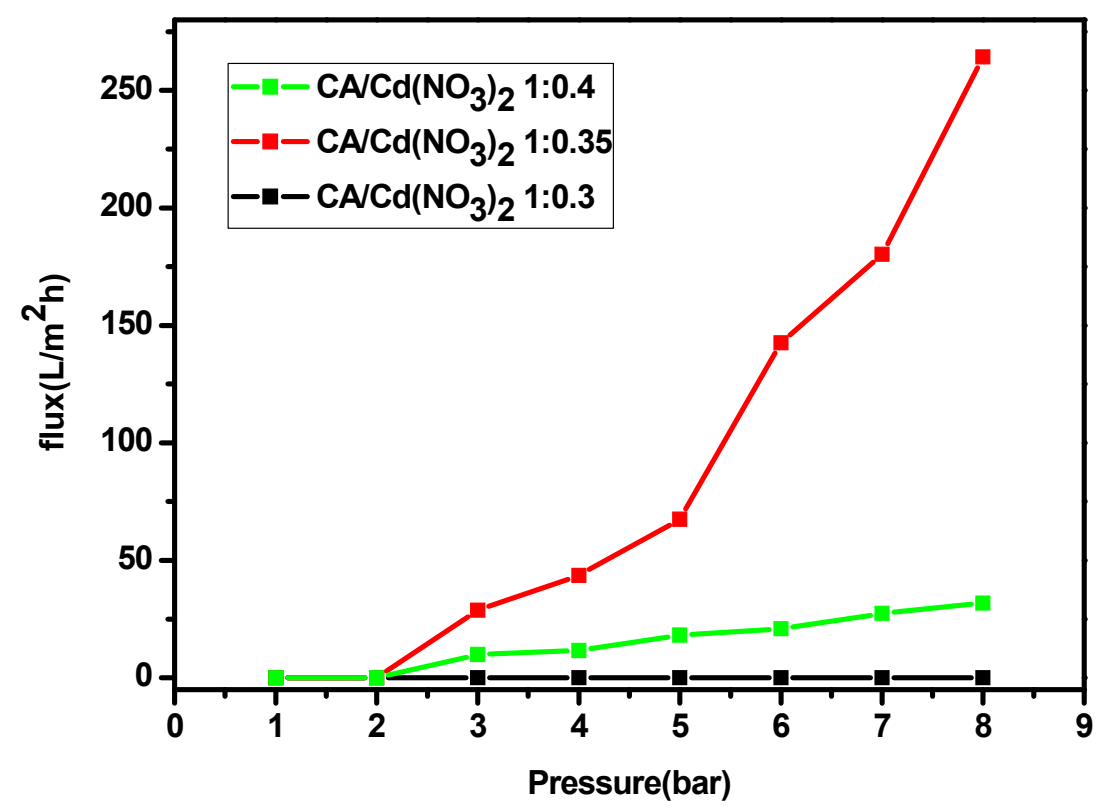

Figure 2. Flux measured through neat $\mathrm{CA}$ and $\mathrm{CA}$ with $\mathrm{Cd}\left(\mathrm{NO}_{3}\right)_{2} \cdot 4 \mathrm{H}_{2} \mathrm{O}$ at various water pressures.

Table 1 showed the comparison of atomic radius and ionic radius of $\mathrm{Cd}, \mathrm{Ni}$ and $\mathrm{Mg}$ utilized in previous with this study to use $\mathrm{Cd}$ salts. As shown in Table 1, the atomic radius and ionic radius of $\mathrm{Cd}$ was largest among the three elements. Thus, it was thought that the $\mathrm{Cd}\left(\mathrm{NO}_{3}\right)_{2}$ that had relatively larger $\mathrm{Cd}$ could easily be dissociated into $\mathrm{Cd}$ ions and $\mathrm{NO}_{3}{ }^{-}$ions. As a result, the free $\mathrm{NO}_{3}{ }^{-}$ions could be readily hydrated with water molecules, resulting in the plasticization effect on the chains of cellulose acetate. Therefore, when the cellulose acetate containing the $\mathrm{Cd}\left(\mathrm{NO}_{3}\right)_{2}$ salts were exposed to high-intensive water-pressure, the pores could be generated more easily than in the other complexes containing Ni or Mg salts.

Table 1. Atomic radius and ionic radius of various elements utilized.

\begin{tabular}{ccc}
\hline Elements & Atomic Radius (pm) & Ionic Radius (pm) \\
\hline $\mathrm{Cd}$ & 155 & 109 \\
\hline $\mathrm{Ni}$ & 135 & 83 \\
\hline $\mathrm{Mg}$ & 150 & 86 \\
\hline $\mathrm{Zn}$ & 135 & 88 \\
\hline
\end{tabular}


To understand the role of $\mathrm{Cd}\left(\mathrm{NO}_{3}\right)_{2} \cdot 4 \mathrm{H}_{2} \mathrm{O}$ solvates during the water pressure process, we performed Fourier transform infrared (FT-IR) spectra. Figure 3a shows the IR spectra of pristine polymer and $1 / 0.35 \mathrm{CA} / \mathrm{Cd}\left(\mathrm{NO}_{3}\right)_{2} \cdot 4 \mathrm{H}_{2} \mathrm{O}$ from 0 bar and 8 bar water pressures, respectively. The pristine polymer in IR spectra was observed at $3500 \mathrm{~cm}^{-1}$, corresponding to the hydroxyl group of the CA polymer. In contrast, the $\mathrm{CA}$ polymer matrix with $\mathrm{Cd}\left(\mathrm{NO}_{3}\right)_{2} \cdot 4 \mathrm{H}_{2} \mathrm{O}$ showed the absorption bands for $\mathrm{CA} / \mathrm{Cd}\left(\mathrm{NO}_{3}\right)_{2} \cdot 4 \mathrm{H}_{2} \mathrm{O}$ at $3400 \mathrm{~cm}^{-1}$, resulting as the abundance of water molecules for $\mathrm{Cd}\left(\mathrm{NO}_{3}\right)_{2} \cdot 4 \mathrm{H}_{2} \mathrm{O}$ caused the intensity of the $\mathrm{OH}$ adsorption peak to be increased. The $\mathrm{CA} / \mathrm{Cd}\left(\mathrm{NO}_{3}\right)_{2} \cdot 4 \mathrm{H}_{2} \mathrm{O}$ composites exposed to 8 bar were observed at the $3400 \mathrm{~cm}^{-1}$, which decreased in intensity and shifted to $3500 \mathrm{~cm}^{-1}$, indicating that a considerable amount of $\mathrm{Cd}\left(\mathrm{NO}_{3}\right)_{2} \cdot 4 \mathrm{H}_{2} \mathrm{O}$ was removed by high water-pressure process. The peak observed at the $1748 \mathrm{~cm}^{-1}$ as shown Figure $3 \mathrm{~b}$ was shifted to $1731 \mathrm{~cm}^{-1}$ for polymer containing $\mathrm{Cd}\left(\mathrm{NO}_{3}\right)_{2} \cdot 4 \mathrm{H}_{2} \mathrm{O}$. This result indicated that the carbonyl group of polymers interacted with the $\mathrm{Cd}$ ion. When the polymer matrix containing $\mathrm{CA} / \mathrm{Cd}\left(\mathrm{NO}_{3}\right)_{2} \cdot 4 \mathrm{H}_{2} \mathrm{O}$ was exposed to external physical forces, most of the $\mathrm{Cd}\left(\mathrm{NO}_{3}\right)_{2} \cdot 4 \mathrm{H}_{2} \mathrm{O}$ was removed from the polymer matrix and recovered to $1748 \mathrm{~cm}^{-1}$. Furthermore, the peak observed at the $1460 \mathrm{~cm}^{-1}$ as shown in Figure $3 \mathrm{~b}$ disappeared when the polymer was exposed to external physical forces. It was also thought that the $\mathrm{Cd}\left(\mathrm{NO}_{3}\right)_{2} \cdot 4 \mathrm{H}_{2} \mathrm{O}$ was removed by physical pressure and the peak of $1460 \mathrm{~cm}^{-1}$ disappeared.

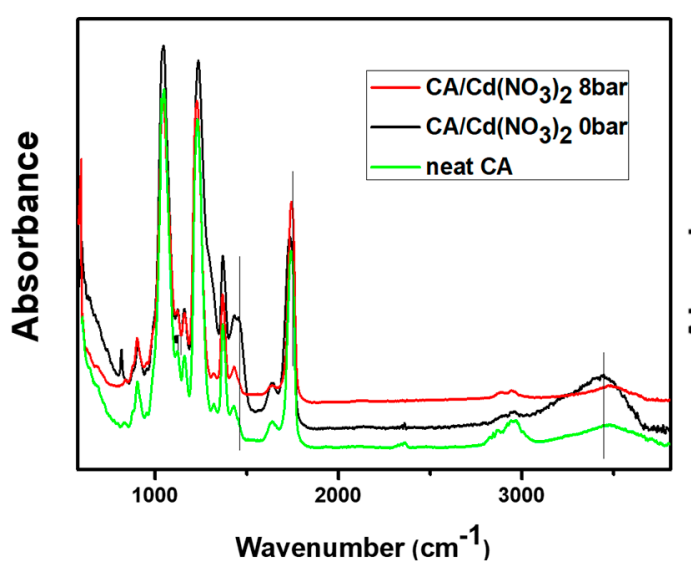

(a)

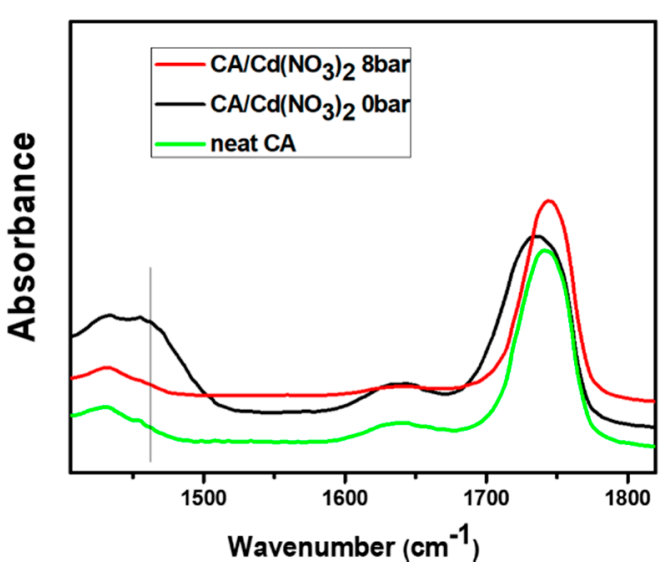

(b)

Figure 3. FT-IR spectra of neat $\mathrm{CA}$ and $1 / 0.35 \mathrm{CA} / \mathrm{Cd}\left(\mathrm{NO}_{3}\right)_{2} \cdot 4 \mathrm{H}_{2} \mathrm{O}$ polymer matrix at 0 bar and 8 bar water pressures: (a) total range and (b) enlarged specific region.

The thermal degradation pattern for polymers was observed by thermogravimetric analysis (TGA). Figure 4 showed that most of the pristine polymer and CA with $\mathrm{Cd}\left(\mathrm{NO}_{3}\right)_{2} \cdot 4 \mathrm{H}_{2} \mathrm{O}$ exposed at 8 bar were decomposed at around $300{ }^{\circ} \mathrm{C}$. On the other hand, about $60 \mathrm{wt} \%$ of polymer with $\mathrm{Cd}\left(\mathrm{NO}_{3}\right)_{2} \cdot 4 \mathrm{H}_{2} \mathrm{O}$ at 0 bar was degraded at between 200 to $350{ }^{\circ} \mathrm{C}$, and $40 \mathrm{wt} \%$ was degraded at between 350 to $800{ }^{\circ} \mathrm{C}$. Since the boiling point of $\mathrm{Cd}\left(\mathrm{NO}_{3}\right)_{2} \cdot 4 \mathrm{H}_{2} \mathrm{O}$ was known to be $132{ }^{\circ} \mathrm{C}$, it was thought that the chains in polymer were loosened by solvated cadmium nitrate. Thus, the loss of about $60 \mathrm{wt} \% \mathrm{CA}$ with $\mathrm{Cd}\left(\mathrm{NO}_{3}\right)_{2} \cdot 4 \mathrm{H}_{2} \mathrm{O}$ was attributable to the degradation of solvated $\mathrm{Cd}\left(\mathrm{NO}_{3}\right)_{2} \cdot 4 \mathrm{H}_{2} \mathrm{O}$ and loosened polymer chain. However, the thermal stability of the polymer matrix increased after water-pressure treatment. The change in the thermal stability was generated as most of the $\mathrm{Cd}\left(\mathrm{NO}_{3}\right)_{2} \cdot 4 \mathrm{H}_{2} \mathrm{O}$ were removed in the polymer. As a result, the thermal stability of the polymer matrix (with $\mathrm{Cd}\left(\mathrm{NO}_{3}\right)_{2} \cdot 4 \mathrm{H}_{2} \mathrm{O}$ removed) by water-pressure treatment was similar to the neat polymer matrix. 


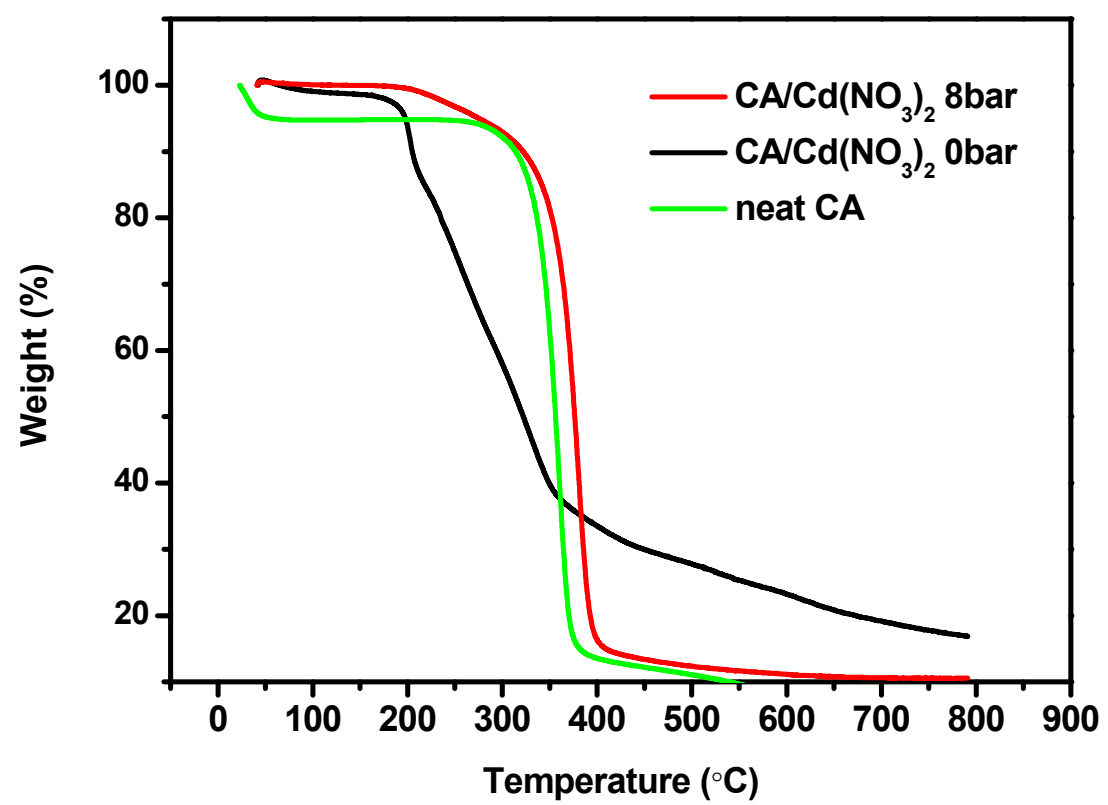

Figure 4. TGA analysis of neat $\mathrm{CA}$ and $\mathrm{CA} / \mathrm{Cd}\left(\mathrm{NO}_{3}\right)_{2} \cdot 4 \mathrm{H}_{2} \mathrm{O}$ polymer matrix at 0 bar and 8 bar.

To investigate the ionic species such as ion aggregates, ion pairs and free ions in $\mathrm{NO}_{3}{ }^{-}$ions for pristine $\mathrm{Cd}\left(\mathrm{NO}_{3}\right)_{2}$ and $\mathrm{Cd}\left(\mathrm{NO}_{3}\right)_{2}$ in the polymer, Raman spectra were acquired as shown in Figure 5 . Since the ionic species of $\mathrm{NO}_{3}{ }^{-}$at 1034 (free ions), 1040 (ion pairs) and 1045 (ionic aggregates) $\mathrm{cm}^{-1}$ was observed, the spectra were focused in the range of 1000 to $1080 \mathrm{~cm}^{-1}$. As shown in Figure 5, the peak of pristine $\mathrm{Cd}\left(\mathrm{NO}_{3}\right)_{2}$ was observed at $1051.5 \mathrm{~cm}^{-1}$.

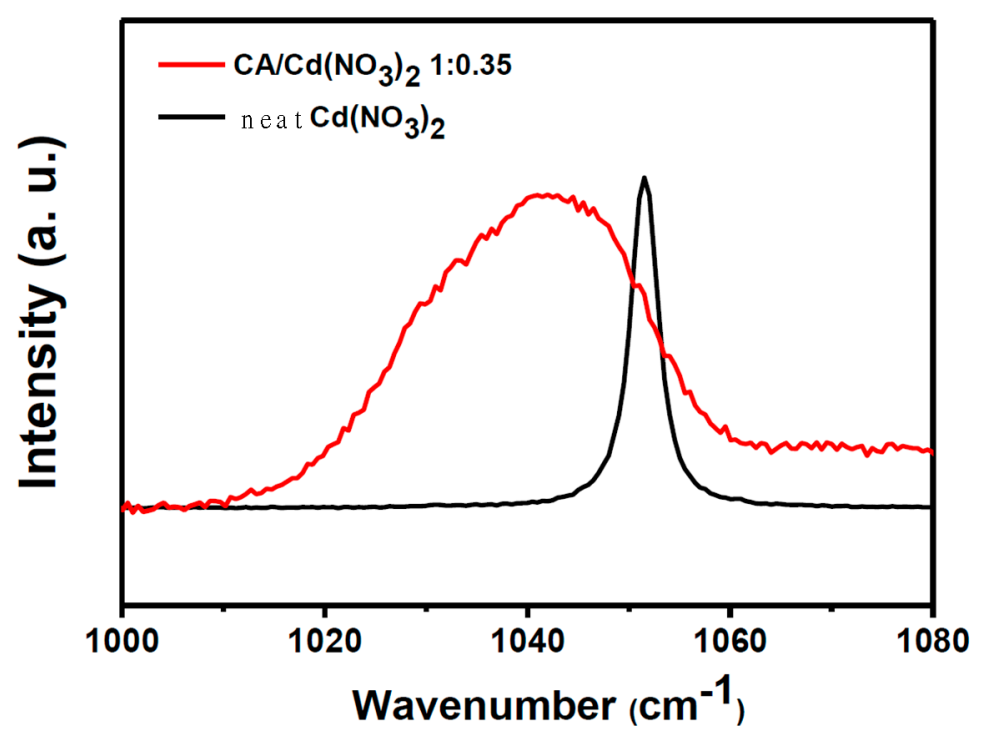

Figure 5. Raman spectra of neat $\mathrm{Cd}\left(\mathrm{NO}_{3}\right)_{2} \cdot 4 \mathrm{H}_{2} \mathrm{O}$ and $\mathrm{CA} / \mathrm{Cd}\left(\mathrm{NO}_{3}\right)_{2} \cdot 4 \mathrm{H}_{2} \mathrm{O}$ polymer matrix.

When $\mathrm{Cd}\left(\mathrm{NO}_{3}\right)_{2}$ was incorporated to the polymer, the peak was shifted from 1051.5 to $1040 \mathrm{~cm}^{-1}$ and was broadened as shown Figure 5, indicating that the $\mathrm{Cd}\left(\mathrm{NO}_{3}\right)_{2}$ incorporated into the CA polymer existed as free ions and ion pairs as well as aggregates. In the case of the $\mathrm{Cd}\left(\mathrm{NO}_{3}\right)_{2}$ incorporated into the CA, the relative percentages for various ionic species were shown in Figure 6. Surprisingly, new peaks were observed at 1034.2 and $1045.6 \mathrm{~cm}^{-1}$, indicating the free ions and ion aggregates. Deconvoluted results were shown for each of the regions in Figure 6. 


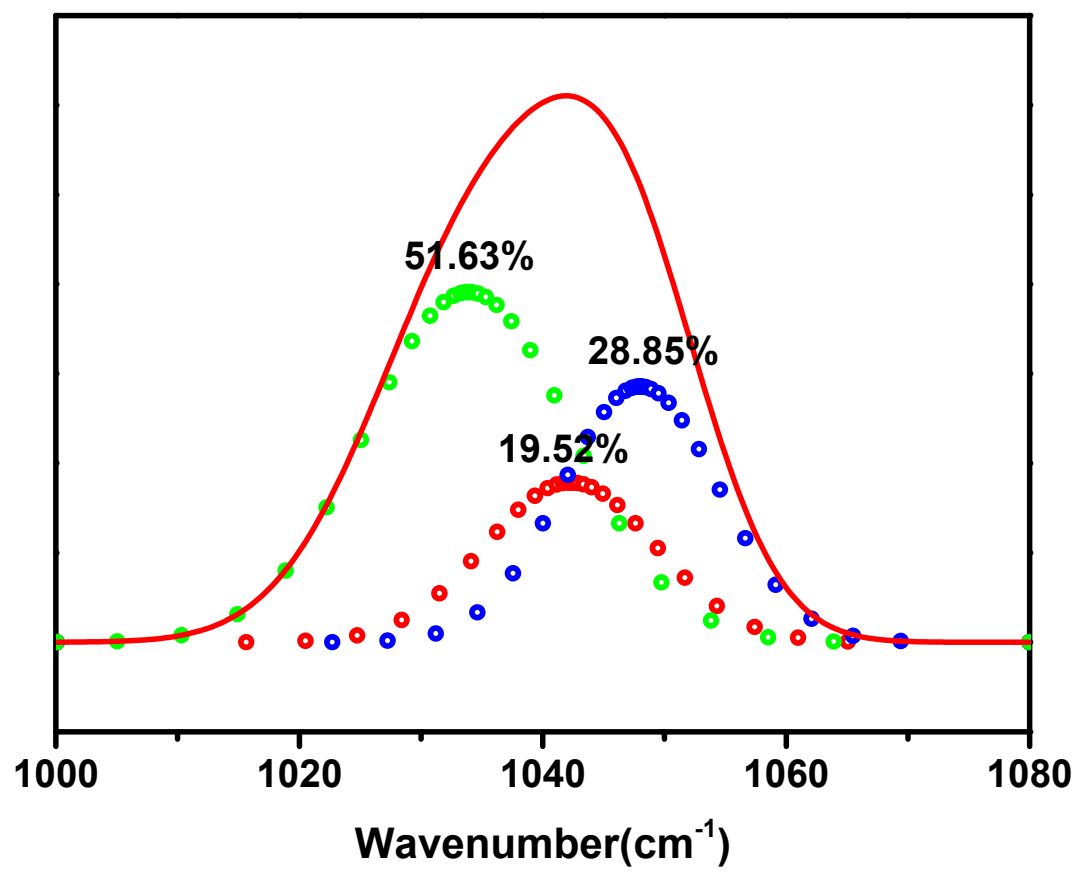

Figure 6. Deconvoluted Raman spectra for $\mathrm{NO}_{3}{ }^{-}$in the $\mathrm{CA} / \mathrm{Cd}\left(\mathrm{NO}_{3}\right)_{2} \cdot 4 \mathrm{H}_{2} \mathrm{O}$ composite.

Based on these results, the $\mathrm{Cd}\left(\mathrm{NO}_{3}\right)_{2}$ incorporated into the polymer existed as abundant free ions in the polymer chain as shown in Table 2.

Table 2. Comparison of free ions, ion pair, and ionic aggregates $\%$ for $\mathrm{NO}_{3}{ }^{-}$in $\mathrm{Cd}\left(\mathrm{NO}_{3}\right)_{2}$ in $\mathrm{CA}$.

\begin{tabular}{cccc}
\hline & Free ions \% & Ion Pair \% & Ionic Aggregates \% \\
\hline $\mathrm{Cd}\left(\mathrm{NO}_{3}\right)_{2}$ in $\mathrm{CA}$ & $51.63 \%$ & $19.52 \%$ & $28.85 \%$ \\
\hline
\end{tabular}

\section{Conclusions}

A porous polymer matrix was successfully fabricated by $\mathrm{Cd}\left(\mathrm{NO}_{3}\right)_{2} \cdot 4 \mathrm{H}_{2} \mathrm{O}$ and external physical forces as shown in Scheme 1. When water pressure as physical force was applied to the polymer matrix, pore size gradually increased. Furthermore, it was observed the water flux increased as the water pressure increased. These results indicated that the water molecule that penetrated into the polymer caused the chains to be weakened by solvated $\mathrm{Cd}\left(\mathrm{NO}_{3}\right)_{2} \cdot 4 \mathrm{H}_{2} \mathrm{O}$. Surprisingly, most of $\mathrm{Cd}\left(\mathrm{NO}_{3}\right)_{2} \cdot 4 \mathrm{H}_{2} \mathrm{O}$ in the polymer was extracted by the external forces. Furthermore, the relationship between radius characteristics in the metal salts and pore generation in the polymer was also investigated. It was found that since $\mathrm{Cd}\left(\mathrm{NO}_{3}\right)_{2}$ had relatively bigger $\mathrm{Cd}$, it could easily be dissociated into $\mathrm{Cd}$ ions and $\mathrm{NO}_{3}{ }^{-}$ions and the free $\mathrm{NO}_{3}{ }^{-}$ions could be readily hydrated with water molecules, resulting in the plasticization effect on the chains of cellulose acetate. Therefore, when the cellulose acetate containing $\mathrm{Cd}\left(\mathrm{NO}_{3}\right)_{2}$ salts were exposed to high-intensive water-pressure, the pores could be more easily generated than other complexes containing $\mathrm{Ni}$ or $\mathrm{Mg}$ salts. Thus, these results were expected to be utilized for designing porous materials with specific pore-sizes. 


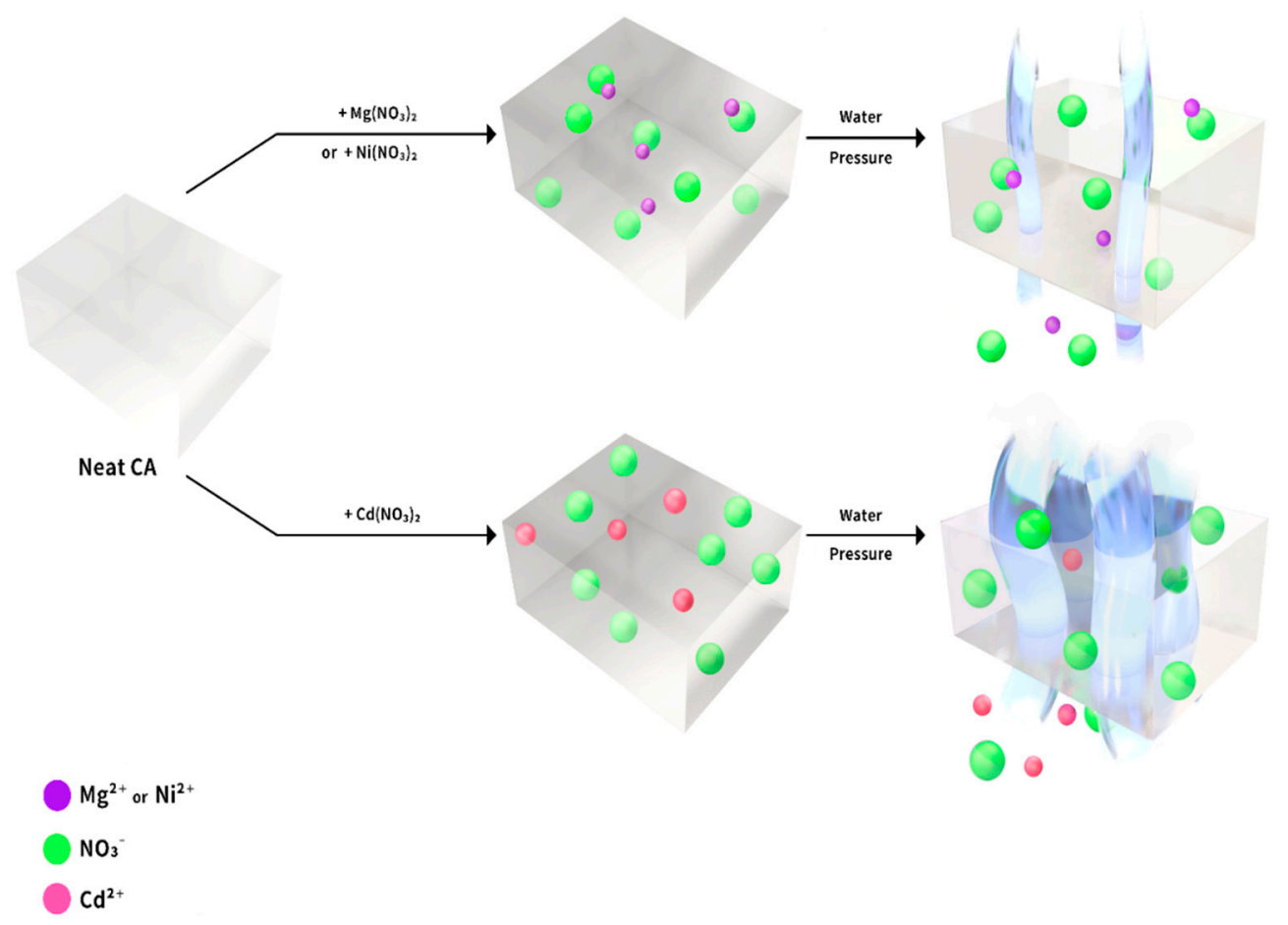

Scheme 1. Comparison of pore generation by species of metal salts in cellulose acetate.

Author Contributions: W.G.L. collected the experimental data and wrote the paper. Y.C. and S.W.K. analyzed the data and reviewed the paper. All authors have read and agreed to the published version of the manuscript.

Funding: This work was supported by the Basic Science Research Program (2017R1D1A1B03032583) through the National Research Foundation of Korea (NRF), funded by the Ministry of Science, ICT, and Future Planning. This work was also supported by the Soonchunhyang University Research Fund (No. 20181002).

Conflicts of Interest: The authors declare no conflict of interest.

\section{References}

1. Fehrmann, R.; Riisager, A.; Haumann, M. Supported Ionic Liquids: Fundamentals and Applications; Willey-VCH: Weinheim, Germany, 2014.

2. Prajapati, A.K.; Mondal, M.K. Hazardous As(III) removal using nanoporous activated carbon of waste garlic stem as adsorbent: Kinetic and mass transfer mechanisms. Korean J. Chem. Eng. 2019, 36, 1900-1914. [CrossRef]

3. Qian, L.; Ahmed, A.; Zhang, H. Formation of organic nanoparticles by solvent evaporation within porous polymeric materials. Chem. Commun. 2011, 47, 10001-10003. [CrossRef]

4. Dubinsky, S.; Petukhova, A.; Gourevich, I.; Kumacheva, E. Hybrid porous material produced by polymerization-induced phase separion. Chem. Commun. 2010, 46, 2578-2580. [CrossRef] [PubMed]

5. Kumar, P.; Vejerano, E.; Khan, A.; Lisak, G.; Ahn, J.H.; Kim, K.-H. Metal organic frameworks (MOFs): Current trends and challenges in control and management of air quality. Korean J. Chem. Eng. 2019, 36, 1839-1853. [CrossRef]

6. Li, W.; Zhang, G.; Zhang, C.; Meng, Q.; Fan, Z.; Gao, C. Synthesis of trinity metal-organic framework membranes for $\mathrm{CO}_{2}$ capture. Chem. Commun. 2014, 50, 3214-3216. [CrossRef] [PubMed]

7. Zhu, J.-H.; Chen, Q.; Sui, Z.-Y.; Pan, L.; Yu, J.; Han, B.-H. Preparation and adsorption performance of crosslinked porous polycarbazoles. Chem. Commun. 2014, 2, 16181-16189.

8. Çalhan, A.; Deniz, S.; Romero, J.; Hasanoğlu, A. Development of metal organic framework filled PDMS/PI composite membranes for biobutanol recovery. Korean J. Chem. Eng. 2019, 36, 1489-1498. [CrossRef] 
9. Zhang, Y.; Li, B.; Williams, K.; Gao, W.-Y.; Ma, S. A new microporous carbon material synthesized via thermolysis of a porous aromatic framework embedded with an extra carbon source for low-pressure $\mathrm{CO}_{2}$ uptake. Chem. Commun. 2013, 49, 10269-10271. [CrossRef]

10. Takase, A.; Kanoh, H.; Ohba, T. Wide carbon nanopores as efficient sites for the separation of $\mathrm{SF}_{6}$ from $\mathrm{N}_{2}$. Sci. Rep. 2015, 5, 11994-11998. [CrossRef]

11. Xu, Q.; Kong, Q.; Liu, Z.; Zhang, J.; Wang, X.; Yue, R.L.L.; Cui, G. Polydopamine-coated cellulose microfibrillated membrane as high performance lithium-ion battery separator. RSC Adv. 2014, 4, 7845-7850. [CrossRef]

12. Lee, M.J.; Kim, J.H.; Lim, H.-S.; Lee, S.Y.; Yu, H.K.; Kim, J.H.; Lee, J.S.; Sun, Y.-K.; Guiver, M.D.; Suh, K.D.; et al. Highly lithium-ion conductive battery separators from thermally rearranged polybenzoxazole. Chem. Commun. 2015, 51, 2068-2071. [CrossRef]

13. Peng, K.; Wang, B.; Li, Y.; Ji, C. Magnetron sputtering deposition of $\mathrm{TiO}_{2}$ particles on polypropylene separators for lithium-ion batteries. RSC Adv. 2015, 5, 81468-81473. [CrossRef]

14. Zhao, M.; Wang, J.; Chong, C.; Yu, X.; Wang, L.; Shi, Z. An electrospun lignin/polyacrylonitrile nonwoven composite separator with high porosity and thermal stability for lithium-ion batteries. RSC Adv. 2015, 5, 101115-101120. [CrossRef]

15. Sun, L.; Tang, S. Synthesis of bi-functionalized ionic liquid mesoporous alumina composite material and its $\mathrm{CO}_{2}$ capture capacity. Korean J. Chem. Eng. 2019, 36, 1708-1715. [CrossRef]

16. Scrosati, B.; Hassoun, J.; Sun, Y.-K. Lithium-ion batteries. A look into the future. Energy Environ. Sci. 2011, 4, 3287-3295. [CrossRef]

17. Chung, S.-H.; Manthiram, A. High-performance Li-S batteries with an ultra-lightweight MWCNT-coated separator. J. Phys. Chem. Lett. 2014, 5, 1978-1983. [CrossRef]

18. He, M.; Zhang, X.; Jiang, K.; Wang, J.; Wang, Y. Pure inorganic separator for lithium ion batteries. ACS Appl. Mater. Interfaces 2015, 7, 738-742. [CrossRef]

19. Lee, J.; Lee, C.L.; Park, K.; Kim, I.D. Synthesis of an $\mathrm{Al}_{2} \mathrm{O}_{3}$-coated polyimide nanofiber mat and its electrochemical charateristics as a separator for lithium ion batteries. Power Source 2014, 248, 1211-1217. [CrossRef]

20. Lloyd, D.R.; Kim, S.S.; Kinzer, K.E. Microporous membrane formation via thermally-induced phase separation. II. Liquid-Liquid phase separation. J. Membr. Sci. 1990, 52, 239-250. [CrossRef]

21. Mo, D.; Liu, J.D.; Duan, J.L.; Yao, H.J.; Latif, H.; Cao, D.L.; Chen, Y.H.; Zhang, S.X.; Zhai, P.F.; Liu, J. Fabrication of different pore shapes by multi-step etching technique in ion-irradiated PET membranes. J. Membr. Sci. 2014, 333, 58-63. [CrossRef]

22. Apeal, P.Y.; Ramirez, P.; Blonskaya, I.V.; Orelovitch, O.L.; Sartowska, B.A. Accurate characterization of single track-etched, conical nanopores. Chem. Commun. 2014, 16, 15214-15223. [CrossRef] [PubMed]

23. Zhao, J.; Luo, G.; Wu, J.; Xia, H. Preparation of microporous silicone rubber membrane with tunable pore size via solvent evaporation-induced phase separation. ACS Appl. Mater. Interfaces 2013, 5, 2040-2046. [CrossRef] [PubMed]

24. Hermsdorf, N.; Sahre, K.; Volodin, P.; Stamm, M.; Eichhorn, K.J.; Cunis, S.; Gehrke, R.; Panagiotou, P.; Titz, T.; Muller-Buschbaum, P. Supported particle track eyched polyimide membranes: A grazing incidence small-angle X-ray scattering study. Langmuir 2004, 20, 10303-10310. [CrossRef] [PubMed]

25. Lee, W.G.; Hwang, J.; Kang, S.W. Control of nanoporous polymer matrix by an ionic liquid and water pressure for applications to water-treatment and separator. J. Chem. Eng. 2016, 284, 37-40. [CrossRef]

26. Lee, W.G.; Kim, D.H.; Jeon, W.C.; Kwak, S.K.; Kang, S.J.; Kang, S.W. Facile control of nanoporosity in Cellulose Acetate using Nickel(II) nitrate additive and water pressure treatment for highly efficient battery gel separators. Sci. Rep. 2017, 7, 1287-1295. [CrossRef]

27. Klemm, D.; Heublein, B.; Fink, H.P.; Bohn, A. Cellulose: Fascinating biopolymer and sustainable raw material. Angew. Chem. Int. Ed. Engl. 2005, 44, 3358-3393. [CrossRef]

28. Lee, W.G.; Kang, S.W. Control of Pore in Cellulose Acetate containing Mg salt by Water Pressure Treatment for Applications to Separators. J. Ind. Eng. Chem. 2019, 70, 103-106. [CrossRef]

(C) 2020 by the authors. Licensee MDPI, Basel, Switzerland. This article is an open access article distributed under the terms and conditions of the Creative Commons Attribution (CC BY) license (http://creativecommons.org/licenses/by/4.0/). 